\title{
The Legal Politics of Irrigation Management in Developing Agroindustry in Facing the Industrial Revolution 4.0
}

\author{
Ujang Suratno* \\ Universitas Wiralodra \\ Indramayu, Indonesia \\ *faujura_1804@yahoo.com
}

\begin{abstract}
Water has a very important role in increasing agricultural productivity. Irrigation provides a significant contribution in providing water. The problems are (1) which regulations can be used as a basis for irrigation management in line with the Regional Government Law after Law No. 7 of 2004 concerning Water Resources was declared non-binding based on MK Decision; (2) how to form the regulations that can encourage optimal irrigation management in developing agricultural industries? Specifically, this study uses analytical descriptive method, with a normative juridical approach where legal materials in primary, secondary, and tertiary as the main analysis material. The results of the study on Law No. 11 of 1974 concerning Irrigation, PP No. 23 of 1982 concerning Irrigation, PP No. 20 of 2006 concerning Irrigation, Law No. 23 of 2014 concerning Regional Government jo Law No. 9 of 2015 show that existing regulations cannot be used as a basis for irrigation management, and are not in line with the Regional Government Law. The formation of regulations is carried out through a comprehensive, integrated and harmonized legal construction.
\end{abstract}

Keywords: regulation, harmoinization, optimization

\section{INTRODUCTION}

As a basic human need and development, water is increasingly becoming a problem. It is not only in terms of quantity but also quality. Due to quantity problems, the competition of the water used is increasingly widespread. Previously, water conflicts were only limited between farmers, now it has developed more broadly, namely conflicts between the sectors and interests [1]. Further developments in this era of globalization show that the treatment of water resources has been seen as economic goods rather than just public goods [2], so it is necessary to make appropriate arrangements in distributing water distribution for various needs.

Article 33 paragraph (2) of the 1945 Constitution states, "The earth and water and the natural resources contained in are controlled by the State and used for the maximum prosperity of the people". This implies that the state has an obligation to distribute water fairly so that water can be used by all Indonesian people to increase the people's prosperity. To regulate and distribute water, the Government has issued Law No. 11 of 1974 concerning Irrigation, which was then replaced by Law No. 7 of 2004 concerning Water Resources. The Law regulates various matters relating to water, from water use rights, utilization of water resources, water management.

Utilization of water resources is carried out through the administration, supply, use, development, and exploitation of water resources by referring to the water resources management pattern determined in each river area. The development of water resources in the river area is intended to increase the utilization of water resources functions to meet the needs of raw water for households, agriculture, industry, tourism, defence, mining, family, transportation, and for other purposes [3]. Meeting the needs of raw water for agriculture is done by developing an irrigation system [4].

The development of irrigation systems is very important for ensuring the availability of water for the agricultural industry. Indonesia, which has a very large agricultural land area, needs water regulation so that it can be well distributed, and is efficient and effective in its use. The development of primary and secondary irrigation systems is the authority and responsibility of the Government and Regional Governments. While the development of tertiary irrigation systems becomes the rights and responsibilities of water user Farmer Associations. Provisions regarding the development of irrigation systems are further regulated by government regulations [5].

The intended regulation is Government Regulation Number 20 of 2006 concerning Irrigation replacing Government Regulation Number 77 of 2001 concerning Irrigation which amends Government Regulation Number 23 of 1982 concerning Irrigation which refers to Law Number 11 of 1974 concerning Irrigation. Government Regulation No. 20/2006 concerning Irrigation, regulates irrigation systems and distribution of irrigation development and management authority based on Law No. 7/2004 concerning Water Resources. But by ruling the Constitutional Court Number 85 / PUU-XI / 2013 stating that Law No. 7 of 2004 concerning Water Resources and all derivatives in the form of regulations below it is contrary to the 1945 Constitution [6], so it does not have binding legal force. To fill the legal vacuum in its ruling, the Constitutional Court only states that Law Number 11 of 1974 concerning Irrigation has re-applied, but does not mention whether government regulations on irrigation that 
were based on Law Number 11 of 1971 also re-apply automatically, also remembering Government Regulation No. 23 of 1982 has also been abolished with Government Regulation Number 77 of 2001 concerning Irrigation which has a different arrangement. The issue is which Government Regulation applies in terms of implementation of development, construction and management of irrigation. This condition occurred in the implementation of a legal vacuum, which resulted in the implementation of irrigation management not running, so that the condition of the use of irrigation did not increase even though in the 2014-2019 Government Nawacita program, irrigation infrastructures to increase self-sufficiency and food security were priorities.

\section{RESEARCH Methods}

Specifically, this research used analytical descriptive method, with a normative juridical approach that is complemented by comparative juridical, where legal materials, both primary, secondary, and tertiary as the main analysis material, supplemented by primary data in the field.

The technique of gathering legal materials is done through literature study, which consists of primary, secondary and tertiary legal materials [7]. Primary legal materials include: the 1945 Constitution, Law No. 7/2004 concerning Water Resources, Law No. 11/1974 concerning Irrigation, Government Regulation No. 20/2006 concerning Irrigation, Government Regulation No. 77/2001 concerning Irrigation and Government Regulation No. 23 of 1982 concerning Irrigation. Secondary legal materials include: Decision of the Constitutional Court Number 85 / PUU-XI / 2013, Research results, and doctrine. While tertiary legal material in the writing form such as in books, magazines, journals, legal opinions, and others.

The results of the study were analysed through Comparative Juridical Technique, where all similar legal materials were compared and then analysed so that the creation of legislation in the irrigation field that was harmonious, harmonic, efficient, and effective. Analysis techniques are also supported by primary data as a material to strengthen juridical analysis.

\section{DISCUSSION}

There are two conflicting concepts about legal reform as part of legal development. The first is the concept of logic (including positivism) and historical sect. The first equates the legal with the law and thinks that all legal actions (including its renewal) can be automatically done by the law. It is better for the historical sect to oppose legislation as a way to make (and renew) the law because law is not possible to make but must grow on its own from the awareness of legal society [8].

This historical sect was very influential in the Dutch East Indies, both among education and government, this influence continued through the leading customary law experts to the current generation of legal scholars. Thought and attitude of this sect of law has played an important role in maintaining (preservation) customary law as a reflection of the indigenous cultural values of indigenous people and prevent the westernization (Westernization) that is too fast [9]. However, this historical sect has various weaknesses such as this perspective has isolated the natives with present-day relations, therefore in some aspects such as trade are lagging behind.

In the last few years in Indonesia there has been a change in attitudes towards legislation that shows a balance between the desire to conduct legal reform through legislation on one side, and the awareness that in an effort, it is necessary to pay close attention to the values and realities that live in society.

That perspective is in conformity with the thought of Eugen Ehrlich the forerunner of the "Sociological Jurisprudence" flow. The key to Ehrlich's thought is what is called "living law". A good positive law (and therefore effective) is law that appropriate with the "living law" which as an inner order of the community that reflects the values within it. So according to Ehrlich that in making laws, it should be considered what is living in society $[10,11]$

To ensure that its law reform in Indonesia does not fall on the mechanistic application which resulted in legalism understanding, the theoretical conception of law as a tool or a medium of renewal must also be brought closer to the approach of Norhtrop cultural philosophical approach and the approach of "policy-oriented" from Laswell and Mc. Dougal [12]

Discussing about legal development then it must move from the understanding of the law itself. Mochtar Kusumaatmadja. Providing understanding of the law as follows: "The law is not only the principle, the rules governing human life, but also includes the institutions and processes that embody rules in reality.

\section{Mochtar Kusumaatmadja, stated [11,13]:}

"The law is a medium of community renewal. This is based on the assumption that there is orderliness or discipline that is desirable, even deemed necessary. Furthermore, the other assumption contained in the conception of law as a media of community renewal is law as the rules or regulations of the law that has function as a regulator or medium of development in the terms of channelling the direction of human activity towards the purpose desired by development or renewal."

It is in line with Friedman, who stated that law as a medium of social engineering of law is not passive but must be able to be used to change certain situations and conditions towards the purpose intended to be headed appropriate with the will of the community [12]. Thus, the law creates a relatively new state, not merely regulating the direction that is already running.

Law besides having a function as social control (social control), a political instrument (political instrument), it also has a function of social change (law as a tool of social engineering) [13]. Even though this function can be separated academically, in reality it is often an inseparable unit. Law as social control ensures that human behaviour must be in accordance with established rules, so it can create discipline, orderliness, certainty, and justice. At the same time the law also changes human behaviour by giving direction so that the behaviour is more orderly, fair and civilized, as well as being used as a tool for the authorities / government to direct their political goals. 
From the perspective of political instruments, the legal politics in the field of irrigation will certainly be different at each time or in every government regime, which forms a political configuration. According to Mahfud MD [14], the political configuration of a democratic government is certainly different from the non-democratic or authoritarian configuration. During the New Order (Regime) government in line with the centralistic government system in which all matters were almost certain to be the affairs of the Central Government, then irrigation management was very centralistic, so that the role of the Regional Government was very little in the management of irrigation. This is seen in Law No. 11/1974 concerning Irrigation. Article 3 paragraph (1) states: "Water and its sources, including natural resources contained in, are controlled by the State. Furthermore, Article 4 states: "Government authorities as referred to in Article 3 of this Law, can be delegated to Government agencies, both Central and Regional, and or certain legal entities whose terms and procedures are regulated in Government Regulations". Regarding to the irrigation management at that time the Government issued Government Regulation Number 23 of 1982. Article 2 paragraph (1) of the Government Regulation states, "The use and regulation of irrigation water and irrigation networks and their supplementary buildings that are within the Regional territory, are submitted to the Regional Government which concerned by referring to the provisions in this Government Regulation, unless otherwise stipulated in a Government Regulation or Law ". At first glance there is a transfer (decentralization) of management to the Regional Government, but in the next article, such as Article 3, Article 5, Article 25, it shows that all development planning, development and management of irrigation must be determined by the minister.

Irrigation arrangements based on Government Regulation No. 23 of 1982 both the construction, development, and management of irrigation were initially successful. The government, with all its financial capabilities, undertakes the construction of various irrigation systems, both primary and secondary, even tertiary, so that the agricultural sector experiences very high productivity, community farmers experience a deferment of welfare sufficient compared to the past, and culminating in food self-sufficiency, especially rice. But the centralized management pattern, especially in funding irrigation development, is not strong enough to be carried out by the government, especially in terms of maintaining irrigation networks. The weaknesses of irrigation policies based on Government Regulation No. 23/1982 include (1) irrigation development planning carried out by the Regions but must be approved by the Central Government, if it is not in line then planning cannot be implemented, (2) funding for irrigation development, development, management, and maintenance is determined by The Central Government, in the end the Central Government was not able to finance management and maintenance, as a result many irrigation networks were damaged, (3) The Government did not involve the public participation in irrigation financing and management, particularly in primary and secondary irrigation networks. As a result of these weaknesses, in the 1990s the agricultural industry experienced a very drastic reduction, food security descended, therefore the Government's continued to import the rice.

The emergence of the reform movement in early 1999, after the fall of the New Order (Regime) Government, provided an opportunity for the emergence of very strong democratization. The emersion of Law No. 22 of 1999 concerning Regional Government, has given a space to the widest possible autonomy, including autonomy in agriculture, and its infrastructure. The reform movement in the field of irrigation engenders to Government Regulation Number 77 of 2001 concerning Irrigation that replaced the Law No. 23 of 1982. In this Government Regulation in line with the distribution of authority based on the Regional Government Law and the Law on Central and Regional Financial Balance, there is an authority distribution in the development, management and maintenance of irrigation and its funding, as well as giving large enough participation to farmers to participate in irrigation management including primary and secondary irrigation networks. In an effort to make changes, especially changes in the culture of irrigation management at the farm level, various trainings are conducted at the farm level. The enthusiasm of farmers through the Water Users Farmers Association (P3A), the Association of Water Users Farmers Association (GP3A) is very large. In some cases, these conditions have shown the success rate of agricultural productivity in some areas [14].

However, the implementation of the irrigation reform movement came to a halt with the issuance of Law Number 7 of 2004 concerning Human Resources, which subsequently in the Irrigation Arrangement was issued Act Number 20 of 2006 concerning Irrigation. From the beginning, the Water Resources Law has experienced philosophical problems, especially over water use rights and their use. In irrigation arrangements, there is inconsistency and harmony between the torso and the explanation in the Act, and it is not in line with Law Number 32 of 2004 concerning Regional Government. At the implementation level even though there is an article on community participation in irrigation management, but only at the tertiary level. As a result, in its implementation, even though governmental programs on irrigation development are always present in every government, because the central infrastructure is not available in the regions, it is difficult to accelerate irrigation improvement and maintenance, while the concerns and participation of farmers through P3A and GP3A are weakening. As a result, since 1990 until now Indonesia has never been more self-sufficient in food, and continuously imports rice and other foodstuffs, which should be an agrarian country must be able to meet its food needs.

The reversion of irrigation arrangements based on Law Number 11 of 1974, is certainly not the right thing, because as described above the irrigation arrangements based on the Law contain various weaknesses, besides being too centralistic, they also conflict with the spirit of democratization which tends to regulate the management of government affairs are carried out autonomously through the decentralization of functions from the Central Government to Regional Governments, followed by the regulation of financial balance between the Centre and the Regions. This condition also causes several effects on the implementation of irrigation management, including: (1) bearing in mind that the regional autonomy is based on Law 
No. 23 of 2014, the division of authority has been clearly distributed, followed by the division of institutions / organs of each level of government. At the Provincial Government level, there are three principles of the exercise of authority, namely Deconcentration, Decentralization, and Medebewin (assistance), while the regency / city level only has two principles of implementation of authority, namely Decentralization and Medebewin (assistance), therefore if irrigation management is centralized, it is very difficult to manage irrigation at the regency and city level, because there are no central institutions or organizations at the Regency / City level, the implementation of the principle of deconcentration does not exist at the district / city level, therefore the implementation still relies on the organization of the Regency / City area , (2) complaints from the community regarding irrigation development and improvement cannot be immediately responded to by the regions because it is a central affairs, (3) slow irrigation management services, (4) efforts to increase agricultural productivity are not achieved.

For this reason, it is necessary to immediately make and reorganize arrangements regarding Water Resources Management, including irrigation management. Irrigation system development in the future, in addition to having to be harmonized with various regulations relating to the Regional Government system so that the realization of harmonization of laws and regulations on its implementation can be effective, but it must also be harmonized with the development of society that right now has begun to develop the industrial revolution 4.0

Entering the 21st century the strategic environment has experienced drastic changes, both global, regional and national, this is due to globalization driven by the development of science and technology, especially information technology, communication and transportation, which has a pervasive and large-scale phase of change (massive), and very fast (turbulence). Various global issues, such as democratization, human rights, transparency, free markets, rule of law, good governance and clean government very quickly spread throughout the national order, and affect various changes in the national order.

Globalization has entered a new phase, namely the phase of the industrial revolution 4.0. The era of the industrial revolution 4.0, marked by patterns of digital economy, artificial intelligence, big data, robotic, etc., is known as the phenomenon of disruptive innovation. The 4.0 industrial revolution will bring many changes with all the consequences. Prof. Callus Martin Schwab is founder and executive Chairman of the World Economic Forum, who introduced it firstly. In his book The Fourth Industrial Revolution (2017), he mentioned that we are now at the beginning of a revolution that fundamentally changes the way of life, work, and relate to one another.

This change is very dramatic and occurs at an exponential speed. Changes that are very influential in life compared to the previous revolutionary era. During the 1.0 revolution the growth of steam and water-based mechanization and energy as a marker. The 2.0 Industrial Revolution was marked by the development of electric energy and the driving force.
Manufacturing and mass production occur. Telephone, car, and airplane are the highest examples. Changes occur quite quickly in the 3.0 industrial revolution marked by the growth of the electronics-based industry, information technology and automation. Digital technology and the internet began to be known at the end of this era. The industrial revolution 4.0 is marked by the development of the internet of / for Things, its presence is so fast. Many things that were unthinkable before, suddenly appeared and became a new revolution, and opened up a very large business area. The emergence of transportation with ride sharing systems such as Go-jek, Uber, and Grab. The presence of the industrial revolution 4.0, indeed presents new businesses, new jobs, new professions that were not thought of before.

Indonesia, which still has vast agricultural land, is very possible to grow the agroindustry. The future era of agricultural industry is still very much needed, first, that food security is the basis for other resilience such as economic security, social security, political security, even ideological security. Weak food security will greatly disrupt national security. For this reason, it is necessary to develop a technology-based agricultural industry, which grows not only for food intensification, but also food diversification. The era of the Industrial Revolution 4.0 will bring it to the use of digitalization in agricultural development, which must also be followed by the speed of irrigation management as an increase in water use services for increasing food productivity.

The influence of the industrial revolution 4.0 on the legal order in the field of irrigation must be examined critically, carefully and carefully. First, the positive impact of growing digitalization on economic and social development must be addressed in the efforts to utilize digitalization technology and the internet for the progress of agricultural development. The existing and future legal regulations will provide positive benefits and are in harmony with the existing of technology. Innovations and interventions and new discoveries through agricultural technology are not impeded and strengthened by law, so that the creation of legal relevance based on digital human and digital soft skills that support the growth of quality human resources and essential justice. Second, the negative impact of people's behaviour due to the growth and development of digitalization, which results in unfair competition in agriculture using technology, must be anticipated as early as possible by the State by implementing various regulations

\section{CONCLUSION}

The abolition of Law Number 7 of 2004 concerning Water Resources based on the Decision of the Constitutional Court Number 85 / PUU-XI / 2013, and the re-enactment of Law Number 11 of 1974 concerning Irrigation as a basis for irrigation management still creates a legal vacuum in irrigation management, because it is not immediately implementing regulations related to irrigation that refer to the Act applied. Besides that, Law No. 11 of 1974 which included on the products of the New Order (Regime) era that had nondemocratic political configurations which conventional, unlimited interpretative, and centralistic legal characteristics 
were not compatible with the development of a democratic Indonesian society.

The re-enactment of Law Number 11 of 1974, and the legal absence of the implementation of regulations in irrigation management have caused disharmony with the local government system, which has hampered services in the field of irrigation and caused various conflicts in the community in the use of water, it causes the low agricultural productivity. This condition is not very good to increase the growth of the agricultural industry (agroindustry).

\section{RECOMMENDATION}

To improve the agroindustry in order to improve the welfare of farmers, especially during the industrial revolution 4.0 which has already begun, it is necessary to immediately make and re-issue a Law Governing Water Resources to substitute the Law Number 7 of 2004, and as a replacement of Government Regulation Number 20 of 2006 concerning Irrigation. The legal products made should have characteristics in harmony with the conditions of a democratic Indonesian society, and the development of the industrial revolution 4.0 .

\section{REFERENCES}

[1] B. Budhiarto, "Water Guarantee for Farmers," Producing National Workshop on Water Assurance for Farmers 15-17 December 1997 in Bandung. Bandung: Center for Development Dynamics of Padjadjaran
University in Collaboration with the Indonesian Irrigation Network (JKII), National Development Planning Agency, KNI-ICID Komda West Java and The Ford Foundation, p. 70, 1997.

[2] Article 33 of Law No. 7 of 2004 concerning Water Resources.

[3] Article 41 of Law No. 7 of 2004 concerning Water Resources.

[4] Article 41 paragraphs (2) and (3) of Law no. 7 of 2004 concerning Water Resources.

[5] Decision of the Constitutional Court Number 85 / PUU-XI / 2013

[6] S. Hartono, Legal Research In Indonesia at the end 20th Century. Bandung: Alumni, 1994.

[7] L. Rasjidi, Fundamentals of Legal Philosophy. Bandung: Citra Aditya Bakti, 1996.

[8] Carl Friedrich Von Savigny, Von B eruf unser Zeit fur Gasetzbung und Rechtswissenschaft, See to Mochtar Kusumaatmadja. Law, Society, and National Law Development. Bandung: Binacipta, 1976.

[9] L. Rasjidi, Fundamentals of Legal Philosophy. Bandung: Citra Aditya Bakti, 1996

[10] M. Kusumaatmadja, Law, Society, dan National Law Development. Bandung: Binacipta, 1976.

[11] W. Friedman, Legal Theory. London: Steven \& Sons Limited, 1990.

[12] O.S. Soemadiningrat, "The function of law in the era of globalization," scientific oration in the field of legal science in the framework of the graduation ceremony and XVII anniversary of Langlangbuana University, October 30, 1999.

[13] M. Mahfud MD, Political Law in Indonesia. Jakarta: Rajawali Press, 2000.

[14] G. Kurnia, Saving Irrigation Water: Preventing a Water Crisis, Preserving Food Self-Sufficiency and Expanding Water Utilization Opportunities. Bandung: Center for Development Dynamics of Padjadjaran University, 1997. 